\title{
AKTIVITAS ANTIOKSIDAN EKSTRAK UMBI BAWANG TIWAI
}

\author{
(Eleutherine americana Merr)
}

\section{Suroto Hadi Saputra}

Balai Riset dan Standardisasi Industri Samarinda

\begin{abstract}
ABSTRACK
The of research antioxidant activity of tuber extract of bawang tiwai was carried out in the water solvent on $100^{\circ} \mathrm{C}$ combined with ethanol solvent $96 \%$. The parameter of antioxidant activaty with had been analyzed was: total of fenol, total of antioxidant activity, copacity of free radical capture, reduction power, oxygen reactive species. The result of this research was that the total of fenol resulted in ethanol solvent was higher than water solvent, the antioxidant activity of $100 \mathrm{ppm}$ bowang tiwai extract in ethanol solvent is better than in water sofvent, but still lower than vitamin $C$, the capacity of free radical capture combined with ethanol solvent $50 \mathrm{ppm}$ was higher than water solvent $50 \mathrm{ppm}$. but still lower than vitamin $\mathrm{C}$. Reduction power of tuber extract of bawang tiwaj combined with ethanol solvent was hight than water solvent 50 ppm. but still lower than vitamin $C$, and reactive oxygen with ethanol species of tuber extract of bawang tiwai combined with ethanol solvent was better than water, but still lower than vitamin $C$.
\end{abstract}

Key word: Bawang tiwai, fenol, reduction, antioxidant, free radical..

\section{PENDAHULUAN}

Antioksidan didefinisikan sebagai senyawa yang mempunyai struktur molekul yang dapat memberikan elcktronnya dengan cuma-cuma kepada molekul radikal bebas tanpa cerganggu sama sekali fungsinya dan dapat memutus reaksi berantai dari radikal bebas serta mengikat molekul yang sangat reaktif (Winarsi, 2007). Antioksidan juga dapat menghambat reaksi oksidasi dengan cara membiarkan reaksi oksidasi terjadi pada antioksidan tersebut. Antioksidan biasanya berbentuk bahan pereduksi seperti senyawa tiol atau fenol (Junaidi, 2007).

Antioksidan sangat beragam jenisnya, berdasarkan sumbernya antioksidan dibagi dalam dua kelompok, yaitu antioksidan sintetik dan antioksidan alami. Antioksidan sintetik yang paling luas penggunaannya dalam bahan makanan adalah butil hidroksi anisol (BHA), butil hidroksi toluen (BHT), tert-butil hidroksi quinon (TBHQ), Propil Galat, dan Tokoferol. Penggunaan antioksidan sintetik dalam bahan makanan saat ini mendapat sorotan berkaitan dengan keamanan pangan dianggap sebagai karsinogenik (Daniells, 2006). Oleh karena itu minat untuk menggantikan antioksidan sintetik dengan antioksidan alami telah meningkat. Antioksidan alami diperoleh dari tumbuhan. Komponen aktif, seperti fenol, polifenol, dan tokoferol, merupakan produk metabolit skunder yang dihasilkan (diturunkan) pertama kali dari fenil-propanoid, dan dalam kasus tertentu pada beberapa tumbuhan diturunkan dari tirosin. Senyawa fenol dalam pangan alami tersedia sebagai campuran berbagai senyawa yang merupakan gabungan berbagai komponen aktif dalam bentuk bebas, bentuk esterifikasi, bentuk glikosilasi, dan bentuk terikat (Shahidi and Naczk, 1995).

Bawang tiwai (Eleutherine americana Merr) memiliki nama yang berbeda-beda antara lain Bawang Sabrang (Sunda), Brambang Sabrang (Jawa Tengah), Bawang Kapal (Melayu), Bawang hantu/kambe (Kalimantan Tengah/Dayak), Bawang Dayak (Kalimantan Barat), Bawang Dayak, Bawang Hutan, Bawang Bromot/Doyok, dan Tiwai (Kalimantan Timur) (Suroto, 2009). Bawang tiwai memiliki khasiat antara lain scbagai obat peluruh kemih, obat muntah, pencahar, obat penyakit kuning, kanker, kista, prostat, diabetes, asam urat, hipertensi, gangguan pencernaan lambung, kolesterol, gondok, bronkhitis, stamina, gangguan seksual, sakit pinggang, dan pegal-pegal (Subiantoro, 2009). Menurut Suroto dan Sampepana (2007) bahwa Bawang tiwai memiliki senyawa antara lain flavonoid, aldehid keton, asam karboksilat, glikosida, tanin, fenol, karbohidrat, dan protein. Hasil ekstrak bawang tiwai (Eleutherine americana Merr) dengan pelarut methanol dan air panas 
memiliki persen antioksidan sebesar $61 \pm 0,8 \%$ dan $5 \pm 0,3 \%$ (Suroto, 2007). Penelitian ini bertujuan untuk mengetaui aktivitas antioksidan bawang tiwai.

\section{BAHAN DAN METODE}

\section{Bahan dan alat}

Bahan yang digunakan antara lain bubuk umbi bawang tiwai diperoleh dari pedagang, methanol, khloroform, kalium ferrisianida, asam trikloroasetat, etanol, asam klorida, ferri tiosianat, asam tiobarbiturat, 1.1-diphynil-2 pieryihidrazyl (DPPH), buffer fosfat, asam linoleat, tween 20 , ammonium tiosianat, ferri klorida, vitamin C. Alat yang digunakan antara lain tabung reaksi. erlenmyer, pipet tetes, statip, corong pisah, spray, cawan penguat, sliser, gelas piala, pipet volumetrik, blender, destilasi unit, buret, botol ekstraksi, alat ekstraksi (soxlet), , reflux, shaker, rotary vakum evaporator, oven, desikator. neraca analitik, hot plat, spectrofotometer, tanur. dan degester.

\section{Metode}

\section{Persiapan sampel}

Sampel bubuk umbi bawang tiwai $200 \mathrm{~g}$ direndam dengan 3 cairan etanol @ $500 \mathrm{ml}$ selama 24 jam dengan dibantu pengocokan (shaking). Selanjutnya larutan ekstrak disaring dengan menggunakan kertas saring untuk kemudian dipekatkan dengan rotary evaporator. Pengeringan ekstrak selanjutnya dilakukan dengan pengeringan vakum untuk memperoleh padatan ekstrak etanol. Kuantifikasi ekstrak dihitung berdasarkan berat sampel kering udara.

Sampel bubuk umbi bawang tiwai $200 \mathrm{~g}$ direndam dengan 3 cairan air 100 $\mathrm{C} @ 500 \mathrm{ml}$ selama 24 jam dengan dibantu pengocokan (shaking). Selanjutnya larutan ekstrak disaring dengan menggunakan kertas saring untuk kemudian dipekatkan dengan rotary evaporator. Pengeringan ekstrak selanjutnya dilakukan dengan pengeringan vakum untuk memperoleh padatan ekstrak air. Kuantifikasi ekstrak dihitung berdasarkan berat sampel kering udara.

\section{Analisis total fenol}

Total fenol ekstrak umbi bawang tiwai dari dua jenis pelarut (etanol dan air) dianalisis dengan metode Folin-Ciocalteau (Povilaityte and
Venskutonis, 2000) dengan asam galat sebagai standar.

\section{Aktivitas antioksidan total}

Aktifitas antioksidan ekstrak umbi bawang tiwai dari dua jenis pelarut (etanol dan air) pada konsentrasi $10 \mathrm{ppm}$. $50 \mathrm{ppm}$ dan $100 \mathrm{ppm}$ diukur kemampuannya dalam menghambat peroksidasi asam linoleat dalam sistem emulsi. Metode yang digunakan adalah metode Duh et al, (1999) dan Yet et al, (2003). Ekstrak dilarutkan kedalam pelarut sesuai dengan jenis pelarut yang digunakan untuk proses ekstraksi. Sebanyak 0.5 $\mathrm{ml}$ larutan ekstrak dicampur dengan $2,5 \mathrm{ml}$ emulsi asam linoleat dan $2 \mathrm{ml}$ buffer fosfat 0,2 M $\mathrm{pH}$. Emulsi asam linoleat diperoleh dengan cara mencampurkan $0,2804 \mathrm{~g}$ asam linoleat. $50 \mathrm{ml}$ buffer fosfat dan 0,2804 $\mathrm{g}$ tween 20 .

Campuran reaksi kemudian diinkubasi pada suhu $37^{\circ} \mathrm{C}$ selama 5 hari. Setiap hari diambil $0,1 \mathrm{ml}$ campuran reaksi dan kemudian ditambahkan $4.7 \mathrm{ml}$ etanol \& $0 \% ; 0.1 \mathrm{ml}$ amonium tiosianat; dan $0.1 \mathrm{ml}$ ferri klorida 0.02 $M$ dalam $\mathrm{HCl} 3.5 \%$. Bilangan peroksida diukur untuk mengetahui tingkat oksidasi dengan cara mengukur absorbansi pada $500 \mathrm{~nm}$. Persentase penghambatan ekstrak diukur setiap hari dengan rumus sebagai berikut $\%$ penghambatan $=100$ $((\mathrm{Al} / \mathrm{Ao}) \times 100)$. Dimana $\mathrm{Ao}=$ Absorbansi dari kontrol atau tanpa penambahan ekstrak dan $\mathrm{Al}=$ absorbansi dari sampel

\section{Kapasitas penangkapan radikal bebas}

Kapasitas penangkapan radikal bebas diukur dengan menggunakan metode Kim (2005). Larutan ekstrak dipersiapkan dengan melarutkan ekstrak umbi bawang tiwai pada konsentrasi 10 ppm, $25 \mathrm{ppm}$, dan $50 \mathrm{ppm}$ dalam kloroform:metanol (2:1) sebanyak $4 \mathrm{ml}$. Sebanyak $4 \mathrm{ml}$ larutan ekstrak dalam kloroform:metanol (2:I) dicampur dengan I ml larutan DPPH 0,2 mM dalam metanol. Campuran direkasikan selama 30 menit sebelum absorbansi menunjukkan $517 \mathrm{~nm}$. Penurunan absorbansi menunjukkan peningkatan kemampuan penangkapan radikal DPPH. Kemampuan untuk menangkap radikal DPPH dihitung dengan persamaan; Kemampuan penangkapan radikal $(\%)=100 \quad(($ Ao-Al $/$ Aox 100$)$. Dimana Ao $=$ absorbansi dari kontrol atau tanpa penambahan ekstrak dan $\mathrm{Al}=$ absorbansi dari sampel. 


\section{Daya reduksi}

Daya reduksi pada berbagai konsentrasi ekstrak (10 ppm, $25 \mathrm{ppm}$ dan $50 \mathrm{ppm}$ ) ditentukan dengan menggunakan metode Oyaizu (1986) yang dimodifikasi oleh Gulcin ct al, (2003). Larutan ekstrak dibuat dengan berbagai konsentrasi yang diuji menggunakan buffer fosfat. Larutan ekstrak sebanyak $0.1 \mathrm{ml}$ ditambah dengan $0.25 \mathrm{ml}$ buffer fosfat (0.2 M; pH 6.6) dan $0.25 \mathrm{ml}$ kalium ferrisianida । \%. Campuran diinkubasi pada suhu $50^{\circ} \mathrm{C}$ selama 20 menit. Kemudian ditambahkan $0,25 \mathrm{ml}$ asam trikloroacetat dan disentrifugasi selama 10 menit pada kecepatan $1700 \mathrm{rpm}$ dan suhu $25^{\circ} \mathrm{C}$. Sebanyak $0,25 \mathrm{ml}$ supermatan dicampur dengan $0,25 \mathrm{ml}$ aquades dan $0,05 \mathrm{ml}$ ferri klorida $0,1 \%$, Absorbansi diukur pada panjang gelombang 700 $\mathrm{nm}$. Peningkatan absorbansi menunjukkan peningkatan daya reduksi.

\section{Spesies oksigen reaksif}

\section{Metode Uji Lipid Peroksidasi dengan Uji Besi Tiosianat}

$4000 \mathrm{PL}$ ekstrak dengan konsentrasi $50 \mathrm{ppm}$, $500 \mathrm{ppm}$ dan $5000 \mathrm{ppm}$ dan vitamin $C$ dengan konsentrasi $50 \mathrm{ppm}$ dimasukan dalam $4.1 \mathrm{~mL}$ asam linoleat yang berisi $8 \mathrm{~mL}$ buffer fosfat lalu tambahkan $3.9 \mathrm{~mL}$ aquades. Masukan dalam vial yang bertutup dan inkubasi di penangas air suhu $40^{\circ} \mathrm{C}$. Setiap hari ambil $0.1 \mathrm{~mL}$ sampel tersebut dan reaksikan dengan $9.9 \mathrm{ml}$ pereaksi besi tiosianat, vortex. Pada menit ketiga spektro dengan panjang gelombang $500 \mathrm{~nm}$. Lakukan setiap hari sampai mencapai nilai maksimum (nilai absorbansi menurun). Pada hari terakhir lakukan uji peroksidasi lipid dengan Uji TBA (asam tiobarbiturat)

\section{Metode Uji Lipid Peroksidasi dengan Uji TBA}

Satu $\mathrm{ml}$ sampel pada akhir uji besi tiosianat dircaksikan dengan $4 \mathrm{~mL}$ pereaksi TBA, vortex, masukan dalam penangas air mendidih selama 30 menit. Dinginkan dengan air mengalir, lalu sentrifus dengan kecepatan $6000 \mathrm{rpm}$ sclama 10 menit. Hasil dibaca dengan spektrofotometer panjang gelombang $532 \mathrm{~nm}$. Hasil dinyatakan dalam persen peredaman lipid peroksidasi pada uji TBA $=$ [nilai absorbansi sampel kontrol (AksAko)-sampel ekstrak (Acs-Aeo)/sampel kontrol (Aks-Ako) $] \times 100$

\section{HASIL DAN PEMBAHASAN}

\section{Kadar total fenol}

Senyawa antioksidan alami tumbuhan umumnya adalah senyawa fenolik atau polifenolik (Pratt dan Hudson, 1990). Senyawa fenolik ini bersifat multifungsional dan berperan sebagai antioksidan karena mempunyai kemampuan sebagai pereduksi, penangkap radikal bebas, pengkelat logam, atau pengubah oksigen singlet menjadi bentuk triplet (Su et al., 2004). Berdasarkan hal tersebut kadar total fenol dari ekstrak umbi bawang tiwai pada penelitian ini diukur dan dikorelasikan dengan mekanisme antioksidan yang dikaji yaitu kemampuan penghambatan peroksidasi (aktivitas antioksidan total), kapasitas penangkapan radikal bebas, dan daya reduksi.

Nialai rata-rata kadar total fenol ekstrak umbi bawang tiwai dengan pelarut air $0,026 \pm 0.001 \mathrm{ppm}$ dan pelarut etanol $96 \%$ $0,043 \pm 0.001 \mathrm{ppm}$, kadar total fenol ekstrak umbi bawang tiwai dipengaruhi oleh jenis pelarut. Fenol merupakan senyawa yang bersifat polar sehingga kelarutannya paling tinggi dalam pelarut polar (etanol). Pelarut yang bersifat polar (etanol) mampu melarutkan fenol lebih baik schingga kadarnya dalam ekstrak menjadi tinggi. (Anonim. 2005). Diantara pelarut yang diuji, ekstrak etanol $(96 \%)$, menunjukkan kadar total fenol lebih tinggi dibandingkan dengan pelarut air .

Menurut Gamez-Meza et al., (1999) dalam Widyawati (2005), hasil ekstrak senyawa fenol meningkat seiring dengan bertambahnya polaritas peiarut. Dari hasil penelitian ini diduga senyawa fenolik yang terdapat dalam umbi bawang tiwai terdiri dari berbagai jenis dengan kisaran polaritas yang luas karena dapat larut dalam etanol $96 \%$.

\section{Aktivitas antioksidan total}

Pengujian aktivitas antioksidan pada asam linoleat merupakan sistem pengujian yang digunakan untuk mewakili sistem pangan (Duh et al., 1999). Dengan metode ini kemampuan penghambatan peroksida sebagai produk oksidasi primer oleh ekstrak umbi bawang tiwai pada konsentrasi $10 \mathrm{ppm}, 50 \mathrm{ppm}$, dan $100 \mathrm{ppm}$ dari dua pelarut etanol dan air. Sebagai pembanding digunakan vitamin $C$ komersial pada konsentrasi 10 ppm, 50 ppm dan 100 ppm (Tabcl I). 
Diduga senyawa yang berperan terhadap kemampuan penghambatan peroksidasi lemak dalam ekstrak umbi bawang tiwai adalah golongan senyawa fenol. Kemampuan penghambatan peroksidasi oleh ekstrak umbi bawang tiwai tergantung dari jenis pelarut yang digunakan yang ditunjukkan aktivitas antioksidan. Selain kuantitas, jenis fenol mempengaruhi kemampuan penghambatan peroksidasi. Menurut Su et al., (2004), aktivitas antioksidan senyawa fenolik dipengaruhi oleh jumlah dan posisi gugus hidroksil aromatic, kemampuan penghambatan reaksi berantai pada proses oksidasai lemak semakin efektif dengan cara mendonorkan atom $\mathrm{H}$ atau berperan sebagai akseptor radikal bebas. Faktor lain yang mempengaruhi adalah ukuran molekul yaitu semakin besar ukuran molekul kemampuan menghambat proses oksidasi semakin menurun.

Menurut Cuveliar et al., (2003), pada sistem emulsi kecepatan oksidasi lemak dan perilaku antioksidan berbeda dengan sistem minyak curah karena tergantung dari partisi antioksidan pada antar permukaan. Penggunaan pengemulsi tween 20 dalam sistem emulsi diduga dapat meningkatkan partisi senyawa antioksidan dari ekstrak umbi bawang tiwai. Faktor lain yang mempengaruhi perbedaan aktivitas antioksidan ekstrak umbi bawang tiwai hasil ekstraksi dengan pelarut yang berbeda adalah jenis senyawa yang terekstrak. Dari fenomena ini dapat diketahui bahwa senyawa yang mempunyai aktivitas antioksidan dalam umbi bawang tiwai merupakan senyawa yang cenderung bersifat polar dan semipolar.

Dibandingkan standar vitamin $\mathrm{C}$ komersial pada konsentasi yang sama ( $10 \mathrm{ppm}, 50 \mathrm{ppm}$, dan 100 ppm), ekstrak umbi bawang tiwai dari semua jenis pelarut yang diuji lebih rendah kemampuannya dalam menghambat proses peroksidasi. Kadar total fenol vitamin $C$ lebih tinggi dari kadar total fenol ekstrak umbi bawang tiwai yang menunjukkan kemurnian ekstrak yang rendah, sehingga pada konsentrasi yang sama senyawa antioksidan dalam ekstrak lebih rendah dari senyawa antioksidan dalam vitamin C komersial.

Tabel I. Aktifitas Antioksidan Total Ekstrak Umbi Bawang Tiwai Dari Dua jenis Pelarut Air dan Etanol.

\begin{tabular}{lcc}
\hline \multicolumn{1}{c}{ Sumber antioksidan } & $\begin{array}{c}\text { Konsentrasi sumber } \\
\text { antioksidan }\end{array}$ & $\begin{array}{c}\text { Persen aktifitas } \\
\text { antioksidan total }\end{array}$ \\
\hline Ekstrak Kasar Umbi Bawang Tiwai dengan Air & 10 & $1.56 \pm 0.40$ \\
$100^{\circ} \mathrm{C}$ & 50 & $6.09 \pm 0.08$ \\
\hline Ekstrak Kasar Umbi Bawang Tiwai dengan & 100 & $16.60 \pm 5.46$ \\
Etanol 96\% & 10 & $12.28 \pm 3.53$ \\
\hline & 50 & $56.71 \pm 3.42$ \\
Vitamin C & 100 & $90.18 \pm 0.27$ \\
& 10 & $96.28 \pm 0.35$ \\
& 50 & $97.55 \pm 0.34$ \\
& 100 & $98.38 \pm 0.18$
\end{tabular}

Keterangan: Aktifitos ontioksidan total diukur abs pada $500 \mathrm{~nm}$. Data diperoleh dori tiga kali ulangan. Vitantin C dipergunakan sebogoipembanding

\section{Kapasitas penangkapan radikal bebas}

Menurut Prakash (2001), elektron yang tidak berpasangan pada DPPH memiliki kemampuan penyerapan yang kuat pada panjang gelombang $517 \mathrm{~nm}$ dengan warna ungu. Perubahan warna ungu menjadi kuning terjadi karena perubahan DPPH menjadi DPPH-H (Xu dan $\mathrm{Hu}$, 2004). Antioksidan berperan mendonorkan atom $\mathrm{H}$ sehingga terbentuk DPPH-H tereduksi. Kapasitas penangkapan radikal bebas ditunjukkan dengan persentase berkurangnya warna ungu dari DPPH (Kim, 2005). Pengujian aktivitas antioksidan dengan metode ini menunjukkan kapasitas ekstrak umbi bawang tiwai sebagai antioksidan primer. Ekstrak umbi bawang tiwai dengan pelarut yang berbeda 
menunjukkan kapasitas penangkapan radikal bebas yang berbeda seperti ditunjukkan Tabel 2 .

Menurut Wijoyo (1999), senyawa fenolik yang terkandung dalam umbi bawang tiwai termasuk ke dalam golongan flavonoid. Flavonoid dapat berperan sebagai penangkap anion superoksida dan radikal hidroksi. Kandaswami dan Middleton (1996) menyebutkan bahwa flavonoid bereaksi dengan radikal peroksil dengan cara mendonorkan atom hydrogen menyebabkan terminasi reaksi radikal berantai.

Senyawa fenolik dalam ekstrak umbi bawang tiwai berperan terhadap aktivitas penangkapan radikal yang menunjukkan perannya sebagai antoksidan primer. Hubungan antara kadar total fenol dengan kapasitas penangkapan radikal bebas.,
Kadar total fenol tertinggi diperoleh dari ekstrak etanol $96 \%$, dan terendah air $100^{\circ} \mathrm{C}$. Diduga jenis senyawa fenolik yang terdapat dalam ekstrak umbi bawang tiwai berperan terhadap kemampuan penangkapan radikal bebas, dan masing-masing ekstrak kemungkinan mempunyai jenis senyawa fenolik yang berbeda dan kapasitas antioksidan yang juga berbeda. Menurut Su et al., (2004), antioksidan fenolik dengan gugus hidroksil aromatic lebih banyak mempunyai kemampuan mendonorkan atom $\mathrm{H}$ lebih baik. Efektivitas senyawa antioksidan dipengaruhi oleh banyak faktor terutama energi aktivasi, konstanta kecepatan rcaksi, potensi oksidasi-reduksi, stabilitas terhadap radikal intermediat dan kelarutannya.

Tabel 2. Kapasitos Penangkapan Radikal Bebas Ekstrak Umbi Bawang liwai Dari Dua jenis Pelarut Air don Etanol.

\begin{tabular}{lcc} 
Sumber antioksidan & $\begin{array}{c}\text { Konsentrasi } \\
\text { sumber } \\
\text { antioksidan } \\
(\mathrm{ppm})\end{array}$ & $\begin{array}{c}\text { Persen kapasitas penangkapan } \\
\text { radikal bebas }\end{array}$ \\
\hline Ekstrak Kasar Umbi Bawang Tiwai dengan Air $100^{\circ} \mathrm{C}$ & 10 & $22 \pm 0.007$ \\
\hline Ekstrak Kasar Umbi Bawang Tiwai dengan Etanol $96 \%$ & 50 & $25 \pm 0.002$ \\
& 100 & $31 \pm 0.008$ \\
\hline Vitamin C & 10 & $51 \pm 0.013$ \\
& 50 & $74 \pm 0.006$ \\
& 100 & $78 \pm 0.002$ \\
& 10 & $96 \pm 0.001$ \\
& 50 & $97 \pm 0.001$ \\
& 100 & $97 \pm 0.000$
\end{tabular}

Keterangan: Kapasitos pcnongkopan rodikal bobos diukur abs pada $\pm 517 \mathrm{~nm}$. Data dipcroich dari tiga kali wiongan, Vitamin C dipergunekan sebagai pembending

\section{Daya reduksi}

Daya reduksi merupakan indikator potensi suatu senyawa sebagai antioksidan. Daya reduksi diukur dari kemampuan suatu antioksidan untuk mengubah $\mathrm{Fe}^{3+}$ menjadi $\mathrm{Fe}^{\text {?: }}$ (Kim, 2005). Singh et al., (2005) menambahkan bahwa daya reduksi berkaitan dengan kemampuan senyawa antioksidan mendonasikan atom hydrogen. Senyawa radikal merupakan suatu spesies molekul yang mempunyai elektron yang tidak berpasangan atau mempunyai struktur molckul yang terbuka schingga bersifat reaktif (Anonim,
2006). Senyawa yang mempunyai daya reduksi kemungkinan dapat berperan sebagai antioksidan karena dapat menstabilkan radikal dengan mendonorkan electron atau atom hydrogen schingga senyawa radikal berubah menjadi lebih stabil.

Menurut Hart (1983), fenol merupakan senyawa yang mudah dioksidasai sehingga bersifat sebagai pereduksi. Daya reduksi meningkat dengan bertambahnya konsentrasi ekstrak yang digunakan dalam sistem pengujian Tabel 3. 
Tabel 3. Daya Reduksi Ekstrak Umbi Bawang Tiwai Dari Dua Jenis Pelarut Air dan Etanol

\begin{tabular}{lcc}
\hline Sumber antioksidan & $\begin{array}{c}\text { Konsentrasi sumber } \\
\text { antioksidan }(\mathrm{ppm})\end{array}$ & Daya reduksi \\
\hline Ekstrak Kasar Umbi Bawang Tiwai dengan Air & 10 & $0.26 \pm 0.01$ \\
$100^{\circ} \mathrm{C}$ & 50 & $0.32 \pm 0.01$ \\
\hline & 100 & $0.37 \pm 0.01$ \\
\hline Ekstrak Kasar Umbi Bawang Tiwai dengan & 10 & $0.32 \pm 0.07$ \\
Etanol $96 \%$ & 50 & $0.86 \pm 0.01$ \\
\hline & 100 & $1.02 \pm 0.01$ \\
\hline Vitamin C & 10 & $1.24 \pm 0.02$ \\
& 50 & $1.21 \pm 0.02$ \\
\hline
\end{tabular}

Keterangan: Daya reduksi diukur abs pada $700 \mathrm{~nm}$. Data diperoleh dori tiga kall ulangan Vitamin $C$ dipergunakan sebagal pembanding

Antioksidan mampu mereduksi radikal bebas yang mempunyai energi potensial yang lebih tinggi (Best, 2004 dalam Rohman dan Riyanto, 2005). Menurut Hart (1983), daya reduksi berkaitan dengan kemampuan melepaskan atom $\mathrm{H}$ untuk bereaksi dengan radikal bebas sehingga terbentuk radikal antioksidan. Radikal antioksidan ini distabilisasi melalui proses resonansi dalam struktur cincin aromatiknya.

Daya reduksi setiap ekstrak umbi bawang tiwai dari dua pelarut, dimana standar vitamin C mempunyai daya reduksi lebih tinggi dibandingkan ekstrak umbi bawang tiwai. Bila dibandingkan dengan ekstrak umbi bawang tiwai kemurnian ekstraknya lebih rendah dari vitamin C sehingga pada konsentrasi uji yang sama jumlah senyawa yang berperan sebagai antioksidan lebih rendah.

\section{Spesies oksigen reaktif}

Menurut Winarsi (2007) spesies oksigen reaktif (SOR) atau reactive oxygen species (ROS) merupakan suatu zat pengoksidasi yang sangat reaktif dan tergolong dalam kelompok radikal bebas antara lain radikal ion superoksida $\left(\mathrm{O}_{2}{ }^{\circ}\right)$, radikal peroksil $(\bullet \mathrm{OOH})$, Hidrogen peroksida $\left(\mathrm{H}_{2} \mathrm{O}_{2}\right)$, Radikal hidroksil $\left(\mathrm{OH}^{*}\right)$. Target utama radikal bebas adalah protein, asam lemak bebas tak jenuh dan lipoprotein, serta DNA termasuk karbohidrat. Dari ketiga molekul target tersebut yang paling rentan terhadap serangan radikal bebas adalah asam lemak tak jenuh.
Oksidasi lipid merupakan hasil kerja radikal bebas dan paling mudah pengukurannya, oleh karena itu untuk mempelajari stres oksidatif dilakukan dengan metode peroksidasi lipid. Peroksidasi lipid merupakan inisiasi reaksi berantai oleh radikal hidrogen atau oksigen, yang menyebabkan teroksidasinya asam lemak tak jenuh ganda poly unsaturated fatty acids (PUFA). Hasil penelitian menunjukkan bahwa kontrol (tanpa pemberian ekstrak bawang tiwai), makin lama oksidasi lipid makin meningkat. Dengan adanya antioksidan ekstrak bawang tiwai maka oksidasi lipid yang terjadi makin berkurang (mampu menghambat) proses oksidasi. Vitamin $\mathrm{C}$ mampu menghambat proses oksidasi lebih baik dibandingkan dengan ekstrak bawang tiwai etanol maupun air. Makin tinggi konsentrasi ekstrak bawang tiwai maka makin meningkat pula daya hambat oksidasi yang terjadi Tabel 4 dan 5.

Socatmadji (1998) radikal bebas adalah suatu senyawa atau molckul yang mengandung satu atau lebih elektron tidak berpasangan pada orbital luarnya. Adanya elektron yang tidak berpasangan menyebabkan senyawa tersebut sangat reaktif mencari pasangan, dengan cara menyerang dan mengikat elektron molekul yang berada di sckitarnya.

Winarsi (2007) menyatakan bahwa antioksidan merupakan senyawa pemberi elektron (elektron donor) atau reduktan. Senyawa ini memilki berat molekul kecil, tetapi mampu menginaktivasi berkembangnya reaksi oksidasi, dengan mencegah terbentuknnya radikal 
bebas. Antioksidan merupakan senyawa yang mengikat radikal dan molekul sangat reaktif,

dapat menghambat reaksi oksidasi, dengan

Tabel 4. Spesies Oksigen Reaktif Ekstrak Umbi Bawang Tiwai Dari Dua Jenis Pelarut Air dan Etanol dengan Uji Besi Tiosianat.

\begin{tabular}{|c|c|c|c|c|c|c|c|c|c|}
\hline \multirow[t]{2}{*}{ Sampel } & \multirow{2}{*}{$\begin{array}{c}\text { Konsen } \\
\text { trasi } \\
\text { (ppm) }\end{array}$} & \multicolumn{8}{|c|}{ pada hari ke - } \\
\hline & & 0 & 7 & 2 & 3 & 4 & 5 & 6 & 7 \\
\hline $\begin{array}{l}\text { Kontrol } \\
\text { (aquades) }\end{array}$ & 0 & $\begin{array}{c}0.282+ \\
0.007 \\
\end{array}$ & $\begin{array}{c}0.379+ \\
0.012 \\
\end{array}$ & $\begin{array}{c}0.481+ \\
0.006\end{array}$ & $\begin{array}{c}0.677+ \\
0.026 \\
\end{array}$ & $\begin{array}{c}0.9134 \\
0.067\end{array}$ & $\begin{array}{c}1.071+ \\
0.034\end{array}$ & $\begin{array}{c}1.257+ \\
0.039 \\
\end{array}$ & $1.109 \pm 0.098$ \\
\hline Vitamin C & 50 & $\begin{array}{c}0.273= \\
0.015\end{array}$ & $\begin{array}{c}0.363 \pm \\
0.016\end{array}$ & $\begin{array}{c}0.454 \pm \\
0.015\end{array}$ & $\begin{array}{c}0.573 \pm \\
0.014\end{array}$ & $\begin{array}{c}0.8311 \\
0.028\end{array}$ & $\begin{array}{c}0.892 \pm \\
0.009\end{array}$ & $\begin{array}{c}1.031= \\
0.040\end{array}$ & $1.102=0.030$ \\
\hline $\begin{array}{l}\text { Ekstrak Limbi } \\
\text { Bawang tiwai } \\
\text { dengan } \\
\text { etanol } 96 \%\end{array}$ & $\begin{array}{c}50 \\
500 \\
5000\end{array}$ & $\begin{array}{c}0.281 \pm \\
0.030 \\
0.279= \\
0.030 \\
0.263= \\
0.017\end{array}$ & $\begin{array}{c}0.372 \pm \\
0.012 \\
0.351 \pm \\
0.031 \\
0.343 \pm \\
0.021\end{array}$ & $\begin{array}{c}0.465 \pm \\
0.012 \\
0.424 \pm \\
0.059 \\
0.376 \pm \\
0.014\end{array}$ & $\begin{array}{c}0.595= \\
0.006 \\
0.576= \\
0.010 \\
0.412= \\
0.007\end{array}$ & $\begin{array}{c}0.860= \\
0.009 \\
0.484= \\
0.049 \\
0.434= \\
0.010\end{array}$ & $\begin{array}{c}0.976 \pm \\
0.025 \\
0.948 \pm \\
0.029 \\
0.445 \pm \\
0.012\end{array}$ & $\begin{array}{c}1.123 \pm \\
0.016 \\
1.058 \pm \\
0.008 \\
0.468 \pm \\
0.004\end{array}$ & $0.485=0.08$ \\
\hline $\begin{array}{l}\text { Ekstrak umbi } \\
\text { Bawang tiwai } \\
\text { dengan air } \\
100^{\circ} \mathrm{C}\end{array}$ & $\begin{array}{l}500 \\
5000\end{array}$ & $\begin{array}{c}0.286 \pm \\
0.031 \\
0.285 \pm \\
0.019 \\
0.276 \pm \\
0.015\end{array}$ & $\begin{array}{c}0.371 \pm \\
0.010 \\
0.368 \pm \\
0.021 \\
0.356 \pm \\
0.025\end{array}$ & $\begin{array}{c}0.472 \pm \\
0.011 \\
0.482 \pm \\
0.024 \\
0.412 \pm \\
0.012 \\
\end{array}$ & $\begin{array}{c}0.673 \pm \\
0.006 \\
0.635 \pm \\
0.008 \\
0.442 \pm \\
0.011\end{array}$ & $\begin{array}{c}0.899 \pm \\
0.060 \\
0.773 \pm \\
0.045 \\
0.474 \pm \\
0.010\end{array}$ & $\begin{array}{c}1.033 \pm \\
0.039 \\
1.062 \pm \\
0.037 \\
0.544 \pm \\
0.028\end{array}$ & $\begin{array}{c}1.145 \pm \\
0.013 \\
1.145 \pm \\
0.016 \\
0.611 \pm \\
0.019\end{array}$ & $1.179=0.016$ \\
\hline
\end{tabular}

Keterongan: Spesies oksigen reakuif diukur daiam abs pada $500 \mathrm{~mm}$. Data diperoleh dengan tiga koli ularigan. Vitamin C dipurgunakan sebagai pembanding.

Tabel 5. Spesies Oksigen Reaktif Ekstrak Umbi Bawang Tiwai Dari Dua Jenis Pelaruc Air dan Etanol denga.

\begin{tabular}{lcc}
\multicolumn{1}{c}{ Sumber antioksidan } & $\begin{array}{c}\text { Konsentrasi } \\
(\mathrm{ppm})\end{array}$ & Persen spesies oksigen reaktif \\
\hline Ekstrak umbi bawang tiwai dengan etanol $96 \%$ & 50 & $46.42 \pm 1.28$ \\
& 500 & $56.13 \pm 0.90$ \\
\hline Ekstrak umbi bawang tiwai dengan air $100^{\circ} \mathrm{C}$ & 5000 & $81.32 \pm 2.76$ \\
\hline Vitamin C & 50 & $42.75 \pm 5.05$ \\
& 500 & $45.54 \pm 2.72$ \\
& 5000 & $66.76 \pm 1.30$ \\
\hline
\end{tabular}

Keterangon: Nilai spesies oksigen reaktif diuktur dalam abs pada $532 \mathrm{~nm}$. Data diperoleh dengan tigo kah. Vitomin C dipargunakan sebogoipembonding. 


\section{KESIMPULAN DAN SARAN}

Ekstrak umbi bawang tiwai hasil ekstraksi dengan dua jenis pelarut mempunyai aktivitas antioksidan yang berbeda. Aktivitas antioksidan total dan kapasitas penangkapan radikal bebas ekstrak umbi bawang tiwai berkaitan erat dengan kadar total fenol. Total fenol, aktivitas antioksdan total, kapasitas penangkapan radikal bebas, daya reduksi, dan spesies oksigen reaktif tertinggi diperoleh dari ekstrak etanol. Senyawa antioksidan dalam umbi bawang tiwai termasuk dalam antioksidan primer. Dibandingkan dengan standar vitamin C, aktivitas antioksidan ekstrak umbi bawang tiwai lebih rendah pada konsentrasi uji yang sama. Sebaiknya dilakukan penelitian lanjutan ekstrak umbi bawang tiwai dengan menggunakan pelarut etanol $96 \%$ untuk aplikasi ke produk minyak.

\section{DAFTAR PUSTAKA}

Cuveliar, M.E., L. Lagunes-Galvets, and C. Busct. 2003. Do antioxidants improve the oxidation stability of oil-in-water emulsions? JAOCS $80(11): 1101-1105$.

Duh, P., P. Tu, and G. Yen. 1999. Antioxidant activity of water extract of Harng iyur (Chrysanthemum morifolium Ramat). Lebensm Wiss u Technol 32:269-277.

Gulcin, I., M. Oktay, E. Kirecci, and O.I. Kufrevioglu, 2003. Screening of antiocxidant and antimicrobial activity of anise (Pimpinello onisum) seed extroct. Food Chem. 83:371-382.

Hart. H. 1983. Kimio Organik. Houngton Mfflin Co. Michigan State University, USA. Alih Bahasa S. Ahmadi. Erlangga. Jakarta.

Junaidi L. 2007. Antioksidan Alami: Sumber, Kimia, dan Teknologi Ekstraksi. Warta Industri Hasil Pertanian Volume 24 Nomor 2 Desember 2007. Balai Besar Industri Agro. Bogor.

Kadaswami, C. and E. Middleton, Jr. 1996. Flavonoid as antioxidants. In F. Shahid (ed) Natural antioxidants-Chemestry. Health Effects, and Application. AOCS Press. USA.
Kim, O.S. 2005. Radical Scavinging Capacity and antioxidant Activity of the $E$ Vitamer Fraction in Rice bran, J, Food Sci. $70(3): 208-213$

Kumalaningsih, Sri. 2006. Antioksidan Alami. hlm. 1-20. Cet. I. Trubus Agrisarana, Surabaya.

Prakash, A. 2001. Antioxidont Activity. Medallion Laboratories Analytical Progress Vol. 19 No. 2. Minnesota.

Povilaityle, V. dan P.R. Venskutonis. 2000. Antiocxidant Activity of Purple Peril, Moldavian, Dragonhead, and Roman Chamomile Extract in J.of Food Sci. $70(6): 5951-956$.

Prat, D. E. dan B. J. F. Hudson. 1990. Natural Antioxidants not Exploited Comercially. In B. J. F. Hudson (ed). Food Antioxidants. Elsevier Applicd Science, London.

Rohman dan Riyanto. 2005. Aktivitos Antioksidon Ekstrak Buch Mengkudu (Morinda citrifolia. L). Agritech 25(3): 131-136.

Shahidi, F. dan Naczk, M. 1995. Food Phenolics: Sources. Chemistry, Effects and Applications. Technomic Publishing Company, Lancaster, PA.

Singh, D., P. Marimuthu, C.S. de Heluani, and C. Catalan. 2005. Antimicrobicl and Antioxidant Potentials of Essential Oil and Acetone Extract of Myristica frograns Houtt. (aril part). J. of Food Sci. 70(2): M|4I-M|48.

Subiantoro. 2009. Khasiat Bawong Tiwoi. Samarinda.

Suroto HS., dan Sampepana E, 2007. Analisa Kandungan Kimia Dan Pemanfaoton Bawang Tiwai (Eleutherine americana Merr) Untuk Bahan Baku Industri. Jurnal Riset Teknologi Industri. Balai Riset dan Standardisasi Industri Volume | Nomor I Bulan Juni Tahun 2007. Samarinda.

Suroto HS. 2007. Analisa Bioktif Dan Pemanfactan Bawang Tiwai ( Eleutherine americana Merr) Untuk Bahan Tambahan Pangan. Jurnal Riset Teknologi Industri Volume I Nomor 2 Bulan Desember 2007. Balai 
Riset dan Standardisasi Industri. Samarinda.

Suroto, 2009. Makalah Kolokium Mengenal dan Pemanfaotan Bawang Tiwai untuk Bahan Baku Industri. Balai Riset dan Standardisasi Industri. Samarinda.

Su, Y-L, J-Z, Xu, C. H. Ng,L.K.K Leung, Y. Huang, and Z-Y. Chen. 2004. Antioxidant Activity of Tea Theaflovins and Methylated Catechin in Conola Oil. JAOCS 31(3). 269. 274.

Widyawati. 2005. Potensi Daun Kemangi (Ocimum basilicum Linn) Sebagai Penangkap Radikal Bebas DPPH. Agritech 25(3): 137-142.

Wijoyo, T.H.N. 1999. Profil Kromatografi Lapis Tipis Kandungan Umbi Akar Talinum paniculatum Gaertn dan Talinum triangulare Wilid. Fakultas Farmasi UGM. Yogyakarta.

Winarsi, Hery. 2007. Isoflavon Berbagoi sumber. sifat, dan Manfaatnya poda Penyakit Degeneratif. Gadjah Mada University Press. Yogyakarta.

Winarsi, Hery, 2007. Antioksidan Alami dan Radikal Bebas. Penerbit Kanisius, Yogyakarta.

Xu. J. And Q. Hu. 2004. Effect of Folior Applicotion of Selenium on the Antioxidant Activity of Aqueous and Ethanolic Extracts of Selenium-enriched Rice. J. Agric. Food. Chem. 52:1759-1763.

Yen, G.C., Y.C. Chang, and S.W. Su. 2003. Antioxidant Activity and Active Coumpound of Rice Koji Fermented with Aspergillus candidus. Food Chem. 83:49-54. 